\section{Biofilm Formation on Different Materials Used in Oral Rehabilitation}

Júlio C. M. Souza ${ }^{1,2}$, Raquel R. C. Mota ${ }^{3}$, Mariane B. Sordi ${ }^{1}$ Bernardo B. Passoni ${ }^{1}$, Cesar A. M. Benfatti ${ }^{1}$, Ricardo S. Magini ${ }^{1}$

The aim of this study was to evaluate the density and the morphological aspects of biofilms adhered to different materials applied in oral rehabilitation supported by dental implants. Sixty samples were divided into four groups: feldspar-based porcelain, $\mathrm{CoCr}$ alloy, commercially pure titanium grade IV and yttria-stabilized zirconia. Human saliva was diluted into $\mathrm{BHI}$ supplemented with sucrose to grow biofilms for 24 or $48 \mathrm{~h}$. After this period, biofilm was removed by $1 \%$ protease treatment and then analyzed by spectrophotometry (absorbance), colony forming unit method (CFU. $\mathrm{cm}^{-2}$ ) and field-emission guns scanning electron microscopy (FEG-SEM). The highest values of absorbance and CFU. $\mathrm{cm}^{-2}$ were recorded on biofilms grown on $\mathrm{CoCr}$ alloys when compared to the other test materials for 24 or 48 h. Also, FEG-SEM images showed a high biofilm density on $\mathrm{CoCr}$. There were no significant differences in absorbance and CFU. $\mathrm{cm}^{-2}$ between biofilms grown on zirconia, porcelain and titanium $(p<0.05)$. Microbiological assays associated with microscopic analyses detected a higher accumulation of oral biofilms on $\mathrm{CoCr}$-based materials than that on titanium or zirconia that are used for prosthetic structures.
'Center for Research on Dental Implants (CEPID), Post-Graduation Program in Dentistry (PPGO), School of Dentistry, UFSC Universidade Federal de Santa Catarina, Florianópolis, SC, Brazil ${ }^{2}$ CMEMS, Department of Mechanical Engineering (DEM), Universidade do Minho, Guimarães, Portugal

${ }^{3}$ School of Dentistry, UFP

- Universidade Fernando

Pessoa, Porto, Portugal

Correspondence: Júlio C. M. Souza, CEPID, Edif. CCS, Campus Trindade, 88040-900 Florianópolis, SC, Brasil. Tel:+55-48-3721-9000. e-mail: julio.c.m.souza@ufsc.br

Key Words: biofilms, dental prosthesis, dental materials, dental implantation.

\section{Introduction}

The oral cavity is a complex environment that gathers several substances ranging from food up to and saliva, oral biofilms and their metabolites $(1,2)$. Oral biofilms are well-organized communities of microorganisms surrounded by a polysaccharide-based matrix containing nucleic acids, proteins and $\mathrm{H}_{2} \mathrm{O}$, that are adhered to tooth, dental restorative structures or oral soft tissues $(1,2)$. As a result, the $\mathrm{pH}$ in the oral cavity is frequently altered reaching low values after the intake of acidic substances and/or acids release from oral microbial metabolism (1-4). The temperature also varies temporarily during the intake of warm or cold foods. Moreover, there is a variation of oxygen in the oral cavity, as for instance the low presence or absence of oxygen content in the areas below gingival margin. As a consequence, the microbial colonization in the mouth follows the variation of oxygen and $\mathrm{pH}$ which promotes the preferential growth of aerobic or anaerobic microorganisms (1-4). In fact, the oral cavity has a specific microbiota involving a harmonious relationship with the host tissues under a healthy state. However, an imbalance between microorganisms and host tissues can lead to oral diseases such as gingivitis and periodontitis $(1,3,4)$.

The biofilm formation in the oral cavity is a gradated process consisting of four distinct stages (2): (a) acquired pellicle formation; (b) primary (early) colonization; (c) secondary colonization/co-aggregation; and (d) mature biofilm establishment. The human saliva provides the main source of nutrients for microorganism adhesion and it allows the coating of hard or soft surfaces by a thin (5-10 $\mu \mathrm{m}$ thickness), heterogeneous and acellular pellicle, named acquired pellicle or conditioning film. Thereafter, the early colonization begins through binding primary bacteria to the acquired pellicle (1). The first adherent bacteria (Streptococcus sanguinis, S. oralis, S. gordonii, S. mitis, Actinomyces naeslundii, Capnocytophagaochraceae, S. mutans and S. sobrinus), are weakly and reversibly linked to the acquired pellicle by adhesins, although they may remain and proliferate, starting the phenomena of microbial co-aggregation $(2,5)$. Steptococcus species represent $60-$ $80 \%$ of all primary colonizers. Such co-aggregation is mediated by metabolic and genetic exchange known as quorum sensing (6). The secondary colonization occurs within 3 to 5 days after the beginning of the acquired pellicle deposition (1). In this process, the microorganisms start to multiply and to co-aggregate with partner species leading to the biofilm structural organization. The biofilm maturation is achieved within 2 to 3 weeks $(1,2,5)$.

The biofilm formation on materials for oral rehabilitation also depends on oxygen, nutrients and $\mathrm{pH}(2,7,8)$. In a dental implant-supported prosthesis, the microbial colonization begins at prosthetic areas exposed to the oral environment taking into account that biofilm formation depends on the prosthetic design, surface conditions and the oral microbiota. Indeed, the microbiota present at peri-implant seems to depend on the same factors related to microbiota of natural tooth surfaces (1-4). The growth of biofilms on restorative materials varies depending on the surface roughness which determines the early biofilm interlocking that helps to the maturation process $(2,7,9)$. Teughels et al. 
(2) emphasize that the surface roughness (Ra roughness above $0.2 \mu \mathrm{m}$ ), surface free energy, wettability and chemical composition of metallic materials are dominant factors that influence the biofilm formation on supra or subgingival areas. Previous studies have reported the effect of mixed and one-species biofilms on the degradation and wear of titanium-based materials (13-15). One-species biofilm composed of $S$. mutans grow as agglomerates while the mixed biofilm covered the entire titanium surface for 48 $h$ of growth (13-15).The decrease of $\mathrm{pH}$ was detected after $24 \mathrm{~h}$ that can induce the corrosion of titanium $(14,15)$.

Advances in dental porcelains since the 60's and a substantial increase in the costs of the gold structures in the 70's led to the development of alternative alloys, such as palladium, cobalt-chromium, nickel-chromium and titanium alloys $(10,11)$. Commercially pure titanium and titanium alloys became the most important industrial metals due to their attractive mechanical properties (tensile strength 450-950 MPa), density $\left(4.5 \mathrm{~g} . \mathrm{cm}^{-3}\right)$, high biocompatibility and corrosion resistance $(10,11)$. Recently, there is a trend to develop novel implant or abutments made of zirconia to improve aesthetic results and also to reduce the biofilm accumulation at periimplant areas $(4,12)$.

$\therefore$ However, few studies have reported the adhesion of oral biofilms on zirconia-based structures. There are different in vitro and in vivo methodologies to evaluate the biofilm density, composition and morphology, using human or modified artificial saliva (13-16). A combination of different experimental approaches including microbiological and microscopic techniques can be useful to assess the in vitro biofilm growth on novel materials or structures applied in oral rehabilitation. The main aim of this study was to evaluate the density and morphological aspects of in vitro biofilms grown on different materials used in oral rehabilitation supported by dental implants.

\section{Material and Methods}

\section{Preparation of the Samples:}

Sixty cylindrical samples $(10 \mathrm{~mm}$ in diameter and $2 \mathrm{~mm}$ in height) were divided into four groups: feldspar-based porcelain; CoCr alloy; commercially pure titanium grade IV; and yttria-stabilized tetragonal zirconia polycrystal. Details on the metallic and ceramic materials tested in this study are described in Table 1. Samples were wet ground down to 4000 Mesh by using SiC sandpapers attached to a polishing machine (DPU; Struers, Copenhagen, Denmark). Then, the samples were ultrasonically cleaned in isopropyl alcohol for 10 min followed by cleaning in distilled water for 5 min in ultra-sonic bath (Izasa Jouan J12). Thereafter, the samples were dried in hot air and sterilized by autoclaving at $121^{\circ} \mathrm{C}$ for $15 \mathrm{~min}$. The roughness values of the samples were obtained regarding Ra roughness parameter that consists in the arithmetic mean value between the peak and valley height values in the effective roughness profile. The Ra roughness was recorded at five different areas on each material $(n=25)$ using an optical profilometer (Dektak 150; Veeco, North Bergen, NJ, USA). The measurement length was at $2 \mathrm{~mm}$ and cut off at $0.25 \mathrm{~mm}$ during $30 \mathrm{~s}$ of measurement.

\section{Biofilm Formation:}

Human saliva was obtained from three different participants ranging from 20 to 31 years of age for biofilm formation. Each participant was in good dental and oral health, with no history of antibiotic treatment during the previous 6 months. None of the participants suffered from any systemic or salivary gland disease that could affect salivary secretion. A history of periodontitis or a probing depth more than $6 \mathrm{~mm}$ was the exclusion criteria. Saliva was stimulated by neutral chewing gum previously immersed in deionized water for $24 \mathrm{~h}$. During the first minute, the saliva was swallowed, then $3 \mathrm{~mL}$ was taken from each individual and mixed under vortex. After mixing, the saliva was diluted $(1: 5)$ in a culture medium (BHI, Sigma-Aldrich, St. Louis, MO, USA) containing 5\% sucrose (BHI 5\% S) (16). For this dilution, $6 \mathrm{~mL}$ were collected from saliva and mixed in 24 $\mathrm{mL}$ of $\mathrm{BHI} 5 \% \mathrm{~S}$. The $\mathrm{pH}$ of the culture medium with saliva was recorded at the first moment and after 24 or $48 \mathrm{~h}$ of biofilm growth using a digital potentiometer (Inolab1 and

Table 1. Chemical composition and clinical application of the materials

\begin{tabular}{|c|c|c|}
\hline Materials & Chemical composition ( $\% \mathrm{wt}$ ) & Clinical application \\
\hline $\begin{array}{l}\text { CoCr alloy } \\
\text { (Nobil 4000; Nobilmetal, Italy) }\end{array}$ & $\begin{array}{l}\text { Co (59); Cr (25.5); Mo (5.5) W(5.0); } \\
\text { Ga (3.2); Nb, Fe, B, Si }(<1.0)\end{array}$ & $\begin{array}{l}\text { Prosthetic dental crowns and bridges infrastructures; } \\
\text { Removable dental prosthesis infrastructures }\end{array}$ \\
\hline $\begin{array}{l}\text { Feldspatic porcelain } \\
\text { (Ti-22 porcelain; Noritake, Japan) }\end{array}$ & $\begin{array}{c}87 \% \text { potassium feldspar; } 8 \% \mathrm{ZrO}_{2} ; 5 \% \\
\text { oxide pigments }\left(\mathrm{TiO}_{2}, \mathrm{CuO}, \mathrm{CaO}, \mathrm{Fe} 0\right)\end{array}$ & $\begin{array}{l}\text { Aesthetic layers (veneers) of dental } \\
\text { crowns and metal-ceramic bridges }\end{array}$ \\
\hline $\begin{array}{l}\text { Zirconia } \\
\text { (Zirkonzahn Y-ZTP; Zirkonzahn, Italy) }\end{array}$ & $95 \% \mathrm{ZrO}_{2}$ and $5 \% \mathrm{YO}_{2}$ & $\begin{array}{l}\text { Prosthetic dental crowns and bridges } \\
\text { infrastructures (metal-free) }\end{array}$ \\
\hline $\begin{array}{l}\text { Commercially pure titanium grade IV } \\
\text { (VSMPO TIRUS, USA) }\end{array}$ & $\begin{array}{l}\text { Ti (0.3); Fe (0.2); O (0.015); H } \\
\quad(0.05) ; \mathrm{N}(0.05) \mathrm{C}(0.08)\end{array}$ & $\begin{array}{l}\text { Dental implants; metal-ceramic } \\
\text { prosthesis infrastructures }\end{array}$ \\
\hline
\end{tabular}


sensix electrode 41; WTW Measurement Systems, Inc., Ft. Myers, FL, Germany). The material coupons were placed in 24-well plates containing $2 \mathrm{~mL}$ of BHI $5 \% \mathrm{~S}$ and $0.1 \mathrm{~mL}$ of human saliva. The 24-well plates were subsequently incubated at $36.8{ }^{\circ} \mathrm{C}$ under microaerophilic conditions $\left(\mathrm{CO}_{2} 5 \%\right)$ to mimic the conditions in the oral environment.

\section{Optical Density Analysis (OD):}

Three samples of each material were removed from the medium BHI $5 \% \mathrm{~S}$ after 24 or $48 \mathrm{~h}$ and placed in new 24well plates. Then, the samples were washed three times with PBS and immersed in $1 \mathrm{~mL}$ of 1\% protease (Sigma-Aldrich, USA) for $60 \mathrm{~min}$ at $36.8^{\circ} \mathrm{C}$. That procedure detached the biofilms from the surfaces after the growth period. Then, 0.2 $\mathrm{mL}$ of the suspension containing detached microbial cells and extracellular matrix was collected in triplicate $(n=9)$ and placed in 96-well plates to measure the absorbance of the suspension at $630 \mathrm{~nm}$ using a spectrophotometer (Microplate Reader mod: Stat Fax 3200, Palm City, FL, USA).

\section{Colony Forming Units Analysis (CFU)}

The suspension containing the detached biofilm by protease treatment was used for counting the colony forming units per area (CFU.cm²). A dilution was carried out from collecting $0.1 \mathrm{~mL}$ of the suspension (biofilm and $1 \%$ protease) and diluting in $0.9 \mathrm{~mL}$ of PBS until dilutions at $10^{-4}$ and $10^{-5}$. Dilution was performed in triplicate. Thereafter, $0.05 \mathrm{~mL}$ of the diluted suspension corresponding to each of the respective samples was removed and inoculated on agar plates with $\mathrm{BHI} 5 \% \mathrm{~S}$ medium $(\mathrm{n}=6)$. The agar plates were incubated at $36.8{ }^{\circ} \mathrm{C}$ under a microaerophilic conditions $\left(\mathrm{CO}_{2} 5 \%\right)$.

\section{Field-Emission Guns Scanning Electron Microscopy (FEG-SEM)}

Before FEG-SEM analysis, two coupons of each material covered with biofilms grown for 24 or $48 \mathrm{~h}$ were washed three times in PBS and fixed in 2.5\% glutaraldehyde for 5 $\min$. Then, the coupons were washed three times in PBS and dehydrated through a series of graded ethanol solutions $(50,60,70,80,90$ and 100\%). Then the samples were sputter-coated with gold and analyzed by field-emission gun scanning electron microscopy (FEG-SEM, Fei Quanta $400 \mathrm{FEG}$, Hillsboro, OR, USA) at 5-10 kV.

\section{Statistical Analysis}

The results were statistically analyzed via two-way ANOVA, using a significance level of $p<0.05$. Tukey's test was applied to compare groups.

\section{Results}

\section{Biofilm Analysis}

After $24 \mathrm{~h}$, the $\mathrm{pH}$ of the growth medium containing the biofilm decreased down to $4.17 \pm 0.1$. The biofilm density after 24 or $48 \mathrm{~h}$ growth is represented in this study by the absorbance of the suspension obtained after removal of the biofilm adhered to the surfaces. The results of the absorbance of the suspensions are noticed in Figure 1.

After $24 \mathrm{~h}$, results of absorbance mean values revealed a statistically significant higher biofilm density of biofilm growth on $\mathrm{CoCr}$ surfaces than that on zirconia, titanium or feldspar-based porcelain $(p<0.05)$. The absorbance mean values recorded for the biofilms grown on titanium and zirconia showed no significant differences $(p<0.05)$.
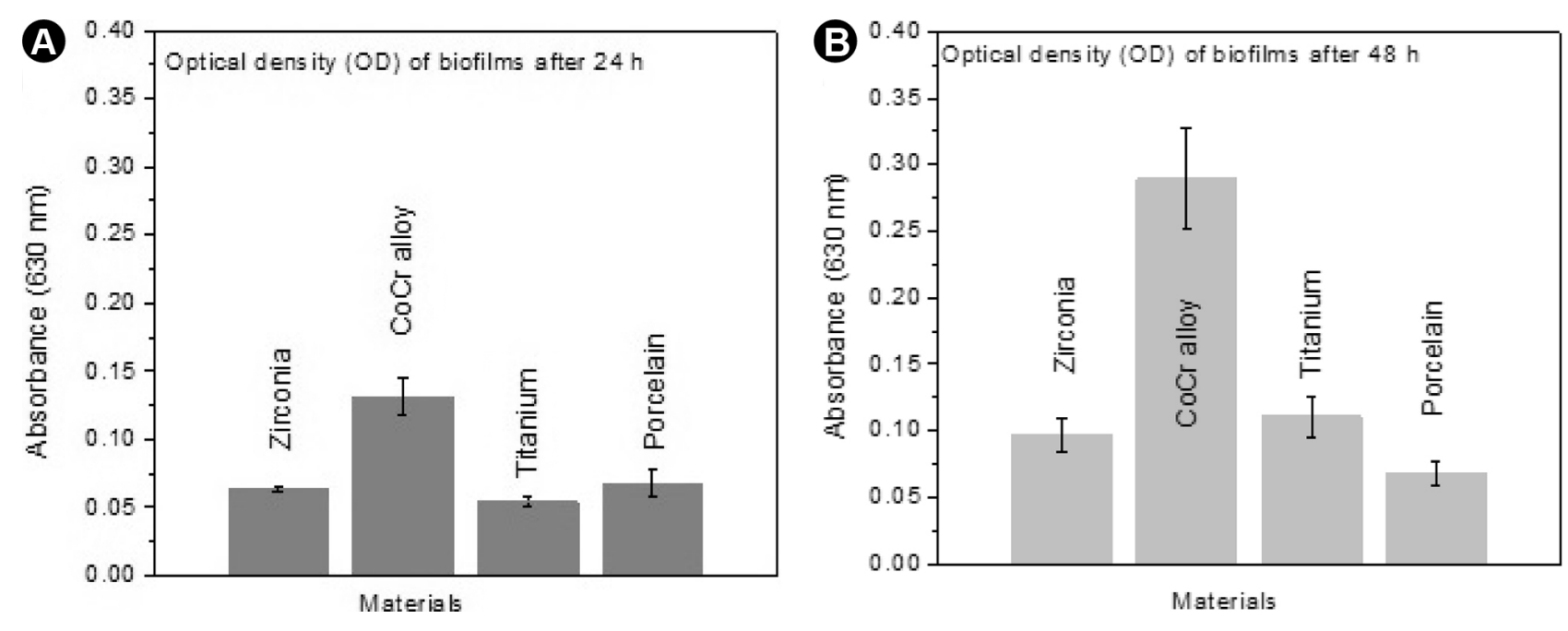

Figure 1. Absorbance results obtained by spectrophotometry at $630 \mathrm{~nm}$ showing the optical density (OD) of the biofilm after $24 \mathrm{~h}$ (A) and $48 \mathrm{~h}$ (B) growth on the different materials and in BHI broth supplemented with 5\% sucrose. 
The biofilm density formed on the $\mathrm{CoCr}$ alloy increased after $48 \mathrm{~h}$ of growth $(\mathrm{p}<0.05)$. Additionally, the highest mean values of absorbance were found for the biofilm grown on the $\mathrm{CoCr}$ alloy when compared to the other materials. Moreover, biofilms formed on the zirconia or titanium also showed higher density after $48 \mathrm{~h}$ of growth than that shown for $24 \mathrm{~h}$ of growth regarding the same material. However, the biofilm grown on feldspar-based porcelain remained stable for 24 and $48 \mathrm{~h}$ of growth.

The mean values of CFU. $\mathrm{cm}^{-2}$ recorded after 24 or 48 $\mathrm{h}$ are shown in Figure 2. The mean values of $\mathrm{CFU}_{\mathrm{cm}}{ }^{-2}$ corroborate with the absorbance results for the biofilm grown for 24 or $48 \mathrm{~h}$ on the different materials tested. Also, the highest mean value of CFU. $\mathrm{cm}^{-2}$ was recorded for the biofilm grown on the $\mathrm{CoCr}$ alloy $(\mathrm{p}<0.05)$, that reveals a larger number microorganisms into the biofilm. However, there was a significant increase in the number of microorganisms in biofilms grown on titanium, $\mathrm{CoCr}$ or porcelain after $48 \mathrm{~h}$ of growth, while the number of microorganisms in biofilms on zirconia remained stable. The $\mathrm{pH}$ of the growth medium after $48 \mathrm{~h}$ of biofilm growth was at $4.3 \pm 0.2$.

\section{Morphological Analyses of the Surfaces}

The highest mean values of Ra roughness were recorded for feldspar-based porcelain $(0.46 \pm 0.1)$ followed by titanium $(0.336 \pm 0.06)$, zirconia $(0.324 \pm 0.06)$ and cobaltchromium surfaces $(0.062 \pm 0.004)$.

The micrographs obtained by FEG-SEM of the biofilms formed on $\mathrm{CoCr}$ alloy, titanium, zirconia or feldspar-based porcelain are shown in Figures 3 and 4. The biofilms morphology can be noticed after 24 and $48 \mathrm{~h}$ of growth on all the materials. After $24 \mathrm{~h}$ of growth, the biofilms revealed the presence of streptococcus. After $48 \mathrm{~h}$, bacillus can be detected in co-aggregation with streptococcus.

\section{Discussion}

The results of this study showed that ceramic surfaces induce low biofilm density associated with a low number of colony forming unit. That can be related to the low intensity of free energy found on ceramic surfaces. Also, the biofilm grown on titanium revealed low density, what can be explained by the presence of the passive film of titanium oxide (mainly $\mathrm{TiO}_{2}$ ). The highest amount of viable microbial cells and biofilm density were noticed on $\mathrm{CoCr}$ for 24 or $48 \mathrm{~h}$ of growth biofilm. The decrease of $\mathrm{pH}$ promoted by biofilm accumulation on the materials tested in this study can induce corrosion of metallic materials, such as titanium or $\mathrm{CoCr}$.

Considering the biofilm formation on titanium surfaces, it was found a lower rate of biofilm growth in the first 24 $\mathrm{h}$, although that increased after $48 \mathrm{~h}$ compared to ceramics (Figs. 1 and 2). Such behavior can be explained by the increase of the passive film dissolution due to the effect of the acidic environment resultant from biofilm metabolism. The corrosion resistance and the biocompatibility of titanium are dependent on the physical-chemical properties of the titanium oxide film $(10,13,14)$. The biofilm morphology was also noticed by electron scanning microscopy, which shows a lower biofilm growth after $48 \mathrm{~h}$ for both feldspar-based porcelain and zirconia when compared to titanium (Figs. 3 and 4). The morphological aspects of biofilms studied in the present study were similar to those found in previous studies $(13,14)$.

Mabboux et al. (17) analyzed two titanium implant materials after immersion in saliva, followed by biofilm formation involving two bacterial strains of streptococci (hydrophilic and hydrophobic). The results confirmed that the physico-chemical properties of the materials play an important role in bacterial retention on the implanted material in presence of adsorbed proteins.
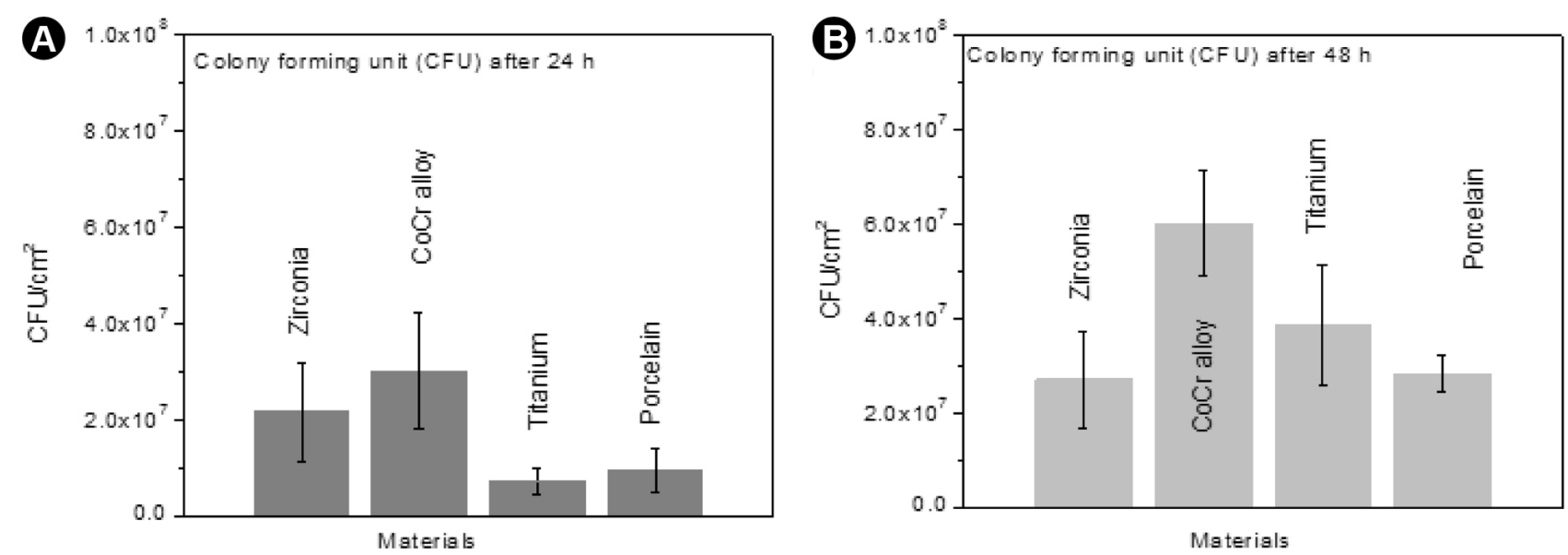

Figure 2. Colony forming unit results after $24 \mathrm{~h}(\mathrm{~A})$ and $48 \mathrm{~h}(\mathrm{~B})$ growth on the different materials and in BHI broth supplemented with 5\% sucrose. 

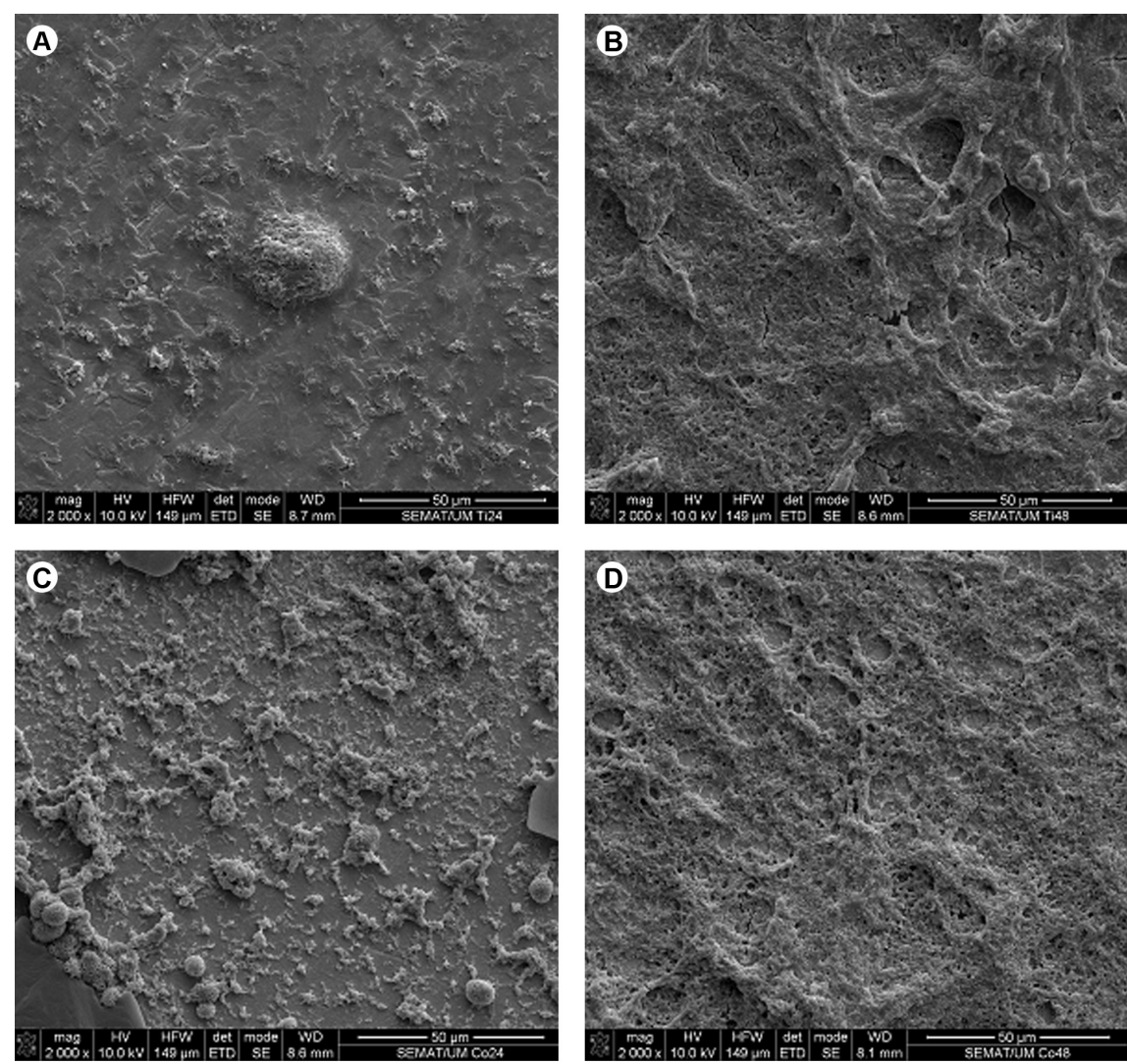

Figure 3. SEM images obtained on commercially pure titanium surfaces (A and B) and CrCoMo alloys (C and D) covered with biofilms after $24 \mathrm{~h}$ (A and C) and $48 \mathrm{~h}$ (B and D) of growth in BHI medium supplemented with 5\% sucrose. Image obtained by secondary electrons mode (SE) at $10 \mathrm{kV}$.
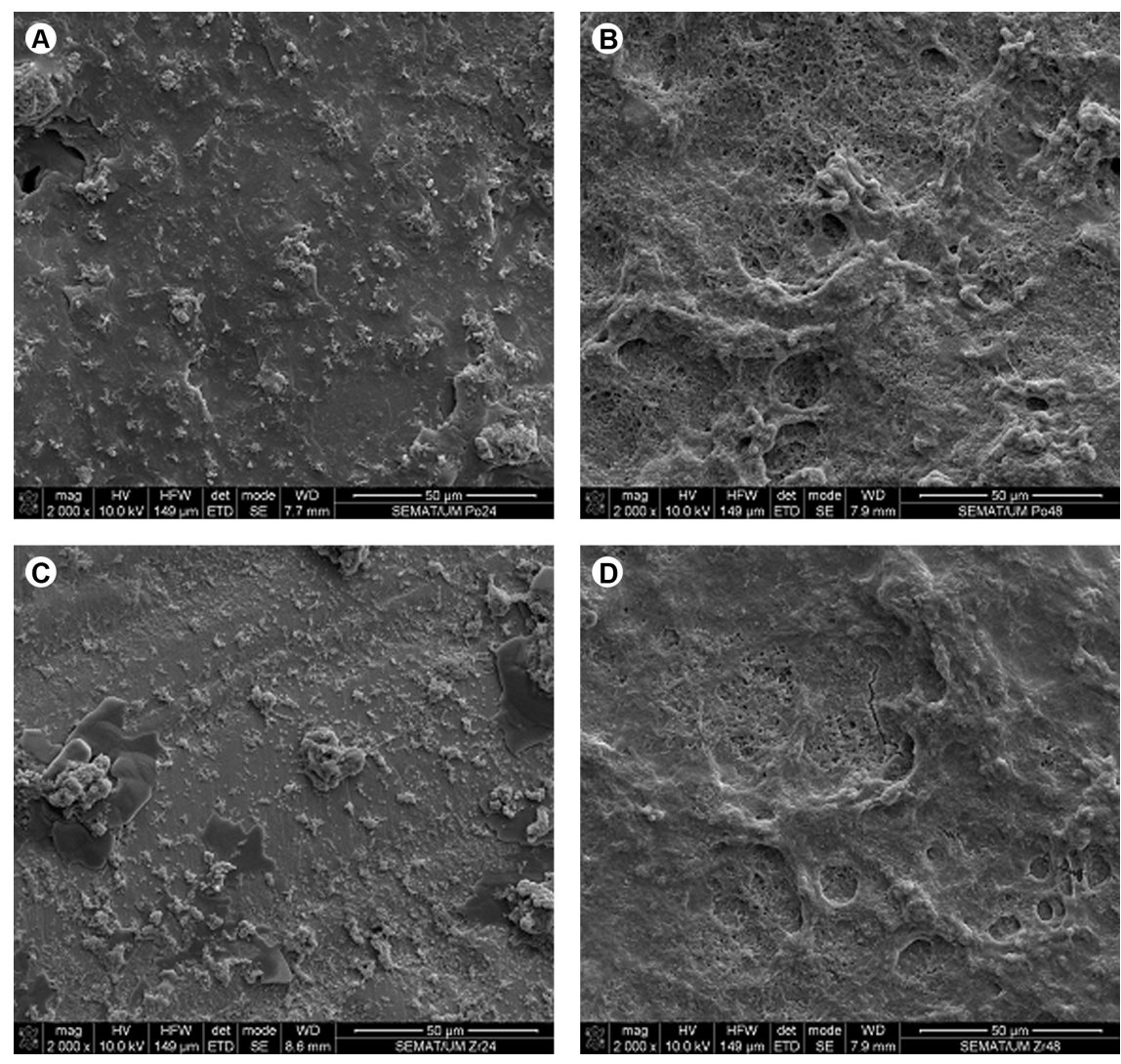

Figure 4. SEM images obtained on feldspar-based porcelain (A and C) and zirconia (B and D) covered with biofilms after $24 \mathrm{~h}$ (A and B) and 48 $\mathrm{h}(\mathrm{C}$ and D) of growth in BHI medium supplemented with 5\% sucrose. Images obtained by secondary electrons mode (SE) at $10 \mathrm{kV}$. 
Rimondini et al. (18) analyzed the adhesion and inhibition of oral microorganism's growth in vitro on zirconia compared to titanium. They concluded that adhesion differences could be observed for some of the selected microorganisms. Scanning electron microscopy analysis revealed a lower biofilm accumulation on zirconia than that on titanium. Scarano et al. (19) showed that the onset of adhesion or bacterial colonization on zirconia surfaces was significantly reduced when compared to titanium. It runs counter to the results found in the present work. Also, the authors have related the lower bacterial growth on zirconia with its low surface free energy (19). Thereby, zirconia is well known to be the material with the highest esthetic potential as an alternative to metalceramic structures for prosthetic rehabilitation (12).

Another previous study revealed a thicker biofilm on the $\mathrm{CoCr}$ surface when compared to the titanium surface, which is in agreement with the results obtained in the present study (20). CoCr alloys are also covered by a thin passive film, which is composed of chromium oxide $\left(\mathrm{Cr}_{2} \mathrm{O}_{3}\right)$. $\mathrm{Cr}_{2} \mathrm{O}_{3}$ passive film is also responsible for the corrosion resistance and biocompatibility of the alloy (21), although those properties are inferior than that of titanium oxide film. Furthermore, the $\mathrm{CoCr}$ alloys have a higher elastic modulus ( $240 \mathrm{GPa}$ ) in comparison with the titanium alloys (140-150 GPa) or commercially pure Ti (100-120 GPa).

Wise and Dikema (22) showed the importance of surface free energy and roughness on the biofilm adhesion and emphasized that the surfaces should be as smooth as possible to minimize such adhesion. The surface free energy have been reported as a determining factor for biofilm formation and bacterial adhesion on titanium surfaces (23). The main outcome resultant from these studies is that the biofilm density on titanium implants surfaces is highly related to the increase of surface roughness. This unfavorable situation can leads to biofilm accumulation and periimplant inflammation resulting in bone loss progression and exposure of the implant rough surface. However, several studies indicate that although the rough titanium surface tends to exhibit increased biofilm growth, the differences in density and viable microbial cells are not statistically significant. Meantime, even with a decrease of roughness, the biofilm formation can still maintain depending on the properties of the surfaces (24).

Several materials have been studied for dental prosthetic rehabilitation, such as ceramics and polymers. However, with the emergence of zirconia, few studies have reported the biofilm behavior on such materials. Therefore, it is suggested future studies on this subject to prove not only the better esthetic effectiveness compared to titanium, but also aiming a functional and biological harmony with the peri-implant tissues.
This in vitro study evaluated the biofilm formation on four different materials used in oral rehabilitation supported by dental implants. A liquid medium containing nutrients and diluted human saliva was used for biofilm growth for 24 and $48 \mathrm{~h}$. After this period, biofilm was detached by physical-chemical treatment and then analyzed by spectrophotometry, colony forming unit method (CFU. $\mathrm{cm}^{-2}$ ) and field-emission guns scanning electron microscopy. Despite the limitations of an in vitro study, the following findings are listed: (1) The highest biofilm density and viable microbial cells were found for biofilm grown on $\mathrm{CoCr}$ alloy when compared to biofilms grown on zirconia, feldspar-based porcelain or titanium; (2) There was a significant increase in biofilm density and number of microorganisms from 24 up to $48 \mathrm{~h}$ of biofilm growth on titanium or $\mathrm{CoCr}$ alloy, while a slight increase of microorganisms was noticed in biofilm grown on feldspar-based porcelain. The biofilm density and number of microrganisms remained stable for biofilm grown on zirconia after 24 or $48 \mathrm{~h}$; (3) The biofilms grown on zirconia or titanium also showed a slight increase in density after 48 $\mathrm{h}$ of growth when compared with that for $24 \mathrm{~h}$ of growth regarding the same material. However, the biofilm density on feldspar-based porcelain remained stable over periods of 24 or $48 \mathrm{~h}$. In fact, the present results indicate a trend towards higher accumulation of oral biofilms on prosthetic structures based on $\mathrm{CoCr}$ when compared to those based on titanium or zirconia.

\section{Resumo}

0 objetivo deste estudo foi avaliar a densidade e os aspectos morfológicos dos biofilmes aderidos a diferentes materiais aplicados em reabilitação oral sobre implantes dentários. Sessenta amostras foram divididas em quatro grupos: porcelana à base de feldspato, liga de $\mathrm{CoCr}$, titânio grau IV comercialmente puro e zircônia estabilizada com itrio. Saliva humana diluida em BHI foi suplementada com sacarose para possibilitar a formação de biofilme por 24 e $48 \mathrm{~h}$. Após este período, o biofilme foi removido utilizando protease a $1 \%$ e, em seguida, analisada por espectrofotometria (absorbância), unidades formadoras de colônia (CFU.cm ${ }^{-2}$ ) e microscopia eletrônica de varredura (MEV). Os valores mais elevados de absorbância e CFU. $\mathrm{cm}^{-2}$ foram encontrados em ligas de CoCr quando comparado com os outros materiais testados. Os resultados obtidos foram semelhantes nos biofilmes formados sobre titânio e zircônia durante 24 e $48 \mathrm{~h}(\mathrm{p}<0,05)$. As análises microbiológicas e microscópicas demostraram uma maior tendência ao acúmulo de biofilmes orais sobre estruturas protéticas baseadas em $\mathrm{CoCr}$ quando comparadas com porcelana feldspática, titânio ou zircônia.

\section{Acknowledgements}

The authors acknowledge the financial support provided by CAPES (Coordenação de Aperfeiçoamento de Pessoal de Nivel Superior - Brazil) and FCT (Foundation for Science and Technology - Portugal).

\section{References}

1. Marsh PD, Martin MV. Oral Microbiology, 4th ed. Oxford: Wright, 1999.

2. Teughels W, Van Assche N, Sliepen I, Quirynen M. Effect of material 
characteristics and/or surface topography on biofilm development. Clin Oral Implants Res 2006;17:68-81.

3. Karring $T$, Lang NP, Lindhe J. Clinical periodontology and implant dentistry, 5th ed. Copenhagen: Munksgaard, 2008.

4. Belibasakis GN, Charalampakis G, Bostanci N, Stadlinger B. Peri-implant infections of oral biofilm etiology. Adv Exp Med Biol 2015;830:69-84.

5. Kolenbrander PE, Andersen RN, Blehert DS, Egland PG, Foster JS, Palmer RJ Jr. Communications among oral bacteria. Microbiol Mol Bio Rev 2002;66:486-505.

6. Donlan RM. Biofilms: microbial life on surfaces. Emerg Infect Dis 2002;8:881-890.

7. Quirynen $\mathrm{M}$, Marechal $\mathrm{M}$, Busscher $\mathrm{HJ}$, Weerkamp AH, Darius $\mathrm{PL}$, Van Steenberghe D. The influence of surface free energy and surface roughness on early plaque formation. An in vitro study in man. J Clin Periodontol 1990;17:138-144.

8. Socransky SS, Haffajee AD. Dental biofilms: Difficult therapeutic targets. Periodontol 2000 2002;28:12-55.

9. Quirynen $M$, Bollen $C M$. The influence of surface roughness and surface-free energy on supra- and subgingival plaque formation in man. A review of the literature. J Clin Periodontol 1995;22:1-14.

10. Niinomi M. Mechanical biocompatibilities of titanium alloys for biomedical applications. J Mech Behav Biomed Mater 2008;1:30-42.

11. Wataha JC. Alloys for prosthodontic restorations. J Prosthet Dent 2002;87:351-363.

12. Bremer $F$, Grade $S$, Kohorst $P$, Stiesch $M$. In vivo biofilm formation on different dental ceramics. Quintessence Int 2011;42:565-574.

13. Souza JCM, Henriques $M$, Oliveira R, Teughels $W$, Celis J-P, Rocha LA. Biofilms inducing ultra-low friction on titanium. J Dent Res 2010a;89:1470-1475.

14. Souza JCM, Henriques M, Oliveira R, Teughels W, Celis J-P, Rocha LA. Do oral biofilms influence the wear and corrosion behavior of titanium? Biofouling 2010b;26:471-478.
15. Souza JCM, Ponthiaux P, Henriques M, Oliveira R, Teughels W, Celis $J-P$, Rocha LA. Corrosion behaviour of titanium in the presence of Streptococcus mutans. J Dentistry 2013;41:528-534.

16. Linardi MM, Rosa OPS, Buzalaf MAR, Torres AS. Utilização de frutooligossacarídeo por Streptococos mutans in vitro. Pesq Odontol Bras 2001;15:12-17.

17. Mabboux F, Ponsonnet L, Morrier JJ, Jaffrezic N, Barsotti O. Surface free energy and bacterial retention to saliva-coated dental implant materials - an in vitro study. Colloids Surf B Biointerfaces 2004;39:199205.

18. Rimondini L, Cerroni L, Carrassi A, Torricelli P. Bacterial colonization of zirconia ceramic surfaces: An in vitro and in vivo study. Int J Oral Maxillofac Implants 2002;17:793-798.

19. Scarano A, Assenza B, Piattelli M, lezzi G, Leghissa GC, Quaranta A, et al.. 16-year study of the microgap between 272 human titanium implants and their abutments. J Oral Implantol 2005;31:269-275.

20. Cho KJ, Jin S, Cui J, Yoon TR, Ryu PY. Effects of biofilm formation on the antimicrobial susceptibility of Staphylococcus aureus. J Bacteriol Virol 2008;38:197-205.

21. Ward BC, Webster TJ. The effect of nanotopography on calcium and phosphorus deposition on metallic materials in vitro. Biomaterials 2006;27:3064-3074.

22. Wise MD, Dykema RW. The plaque-retaining capacity of four dental materials. J Prosthet Dent 1975;33:178-190.

23. Quirynen $M$, De Soete $M$, Van Steenberg D. Infections risk for oral implants: a review of literarture. Clin Oral Impl Res 2002;13:1-19.

24. Schmidlin PR, Müller $P$, Attin $T$, Wieland $M$, Hofer $D$, Guggenheim B. Polyspecies biofilm formation on implant surfaces with different surface characteristics. J Appl Oral Sci 2013;21:48-55.

Received November 3, 2015 Accepted February 22, 2016 